\title{
METRICAL CHARACTERISTICS OF THE CHILDFIT BATTERY of Tests FOR MEASURING Motor ACHIEVEMENTS IN PRESCHOOL CHILDREN
}

\author{
VILKO PETRIĆ
}

Potrjeno/Accepted

23. 11. 2019

Objavljeno/Published

9. 12. 2019

\section{Keywords:}

childfit tests, motor achievements, validity, reliability, early and preschool age

Ključne besede: test Childfit, motorični dosežki, veljavnost, zanesljivost, zgodnje obdobje, predšolsko obdobje

UDK/UDC

373.2:796.012
University of Rijeka, Faculty of Teacher Education, Rijeka, Croatia

KORESPONDENČNI AVTOR/CORRESPONDING AUTHOR

vilko.petric@uniri.hr

\begin{abstract}
Povzetek The aim of this research is to evaluate the Childfit Battery of Tests measuring early and preschool children's motor achievements. The test items that determine the content validity were systematically analysed, the test retest procedure applied and the Pearson's correlation coefficient between two intervals of measurement calculated, all with the aim of determining the test's reliability. All parts of the object of measurement are proportionally present, and the test items are relevant for the same. The correlation of results in two measurement intervals is statistically significant and ranges from 0.91 to 0.94 . The Childfit tests satisfy the validity and reliability criteria and are applicable for the measurement of early and preschool children's motor achievements.
\end{abstract}

\section{Merske značilnosti baterije testov Childfit za merjenje motoričnih dosežkov predšolskih otrok}

Cilj te raziskave je evalviranje baterije testov Childfit Battery of Tests, ki merijo motorične dosežke mlajših in predšolskih otrok. Postavke testa, ki določajo vsebinsko veljavnost, so bile sistematično analizirane $\mathrm{z}$ uporabo postopka testiranja in ponovnega testiranja ter $z$ izračunom Pearsonovega korelacijskega faktorja med dvema intervaloma meritev $\mathrm{z}$ namenom ugotoviti zanesljivost testa. Sorazmerno prisotni so vsi deli predmeta merjenja in postavke testa so zanje relevantne. Korelacija rezultatov $\mathrm{v}$ dveh intervalih meritev je statistično pomembna in se giblje $\mathrm{v}$ razponu $0,91-0,94$. Testi Childfit zadoščajo kriterijem veljavnosti in zanesljivosti ter so uporabni za merjenje motoričnih dosežkov mlajših in predšolskih otrok. 


\section{Introduction}

Motor achievements are defined as a combination of motor knowledge and physical fitness applied by an individual in a certain motor situation with the purpose of solving a particular motor challenge (Findak and Prskalo, 2004). Motor knowledge is the level of acquisition of certain motor structures (Findak, 2003). For early and preschool children, motor achievements are usually based on biotic motor knowledge, i.e. on innate movements that children start to perform independently and naturally without no special help (Petrić, 2019). These are natural forms of movement that enable children to master space, obstacles, resistance and the handling of objects, and thus their motor expression in a space. The most usual elements of biotic motor knowledge are crawling, walking, running, jumping, crawling through, climbing, pushing, lifting, carrying, catching, throwing and leading.

On the other hand, physical fitness is defined as the capability of an individual to competently perform daily life tasks, without excessive tiredness and retaining a sufficient quantity of energy to enjoy their free time and deal with sudden emergencies (Cvejić et al., 2013). Physical fitness dimensions relate to sport success and health. When it comes to children, it has to be considered in terms of health; therefore, it is called health fitness. During childhood and adolescence, it is a key indicator of health (Ruiz et al., 2006). Special consideration is given to components important for the optimal health status that enables an individual to perform everyday activities so as to prevent the occurrence of various chronic diseases and premature death. In fact, health fitness relates to the state of physical and physiological components that indicate the level of risk for the development of noncontagious illnesses. Mild and highly intensive activities stimulate certain functional adaptations of all human tissues and organs, advance physical fitness and significantly diminish the occurrence of degenerative and chronic diseases (Artero et al., 2011). 
Fitness diagnosis in children is conducted by various batteries of tests. An objective way to measure physical fitness is laboratory testing. However, this is extremely expensive and not practical, especially when it comes to children. Therefore, various batteries of tests have developed over the years, thanks to which cheaper, but valid and reliable field measurements can be conducted.

The physical fitness of early and preschool children has been insufficiently studied, and there is not enough data on the topic. Moreover, there is no data about which tests for measuring fitness are more valid, reliable and informative from the point of view of health for early and preschool children. Ortega et al. (2015) have made an overview of research studies using tests to measure preschool children's physical fitness and checked their (1) reliability, (2) validity and (3) correlation between the results and health. The results were based on 22 identified articles. Most of the studies concentrated on the reliability of fitness tests $(n=21.96 \%)$, while a very small number focused on validity ( 0 criterion of correlated validity and $4(18 \%)$ of convergent validity) or on the relation to health outcomes ( 0 longitudinally and 1 $(15 \%)$ cross section). Motor fitness, especially balance, was the most frequently studied fitness component, while cardiorespiratory fitness was the least often studied. The authors concluded that the number of papers was too small to be able to define the acceptable criteria and that there was a great need for further inspection of the validity of fitness tests for preschool children and their correlation with health. The authors made a review of findings from cross studies of physical fitness and health in young people.

The authors Ruiz et al. (2011) carried out three systematic overviews dealing with (1) the predictive validity of fitness linked to health, (2) the validity of field test criteria and (3) the reliability of field fitness tests applied to the young. The authors also carried out 11 methodological examinations to determine the validity criterion and the reliability of some field fitness tests for the young. They concluded that the battery of ALFHA fitness tests is valid, reliable, manageable and safe for estimating physical fitness linked to testing of children and adolescents, and it will be used to monitor health on the level of the whole population. The ALFHA battery of tests is extremely useful, but it does not include early and preschool children. 
In their review of research, Castro-Pinero et al. (2010) presented the metric characteristics of several field batteries of tests used with children and adolescents. They determined that there were differences in reliability between tests, but to a greater or lesser extent, all the field ones were valid. The problem is that these batteries of tests are meant for school children and adolescents, and there is no generally reliable battery of field tests used to estimate motor knowledge and physical fitness among early and preschool children. Owing to this, the Childfit battery of tests has been constructed. In a very economical and simple way, it will measure the motor achievements of early and preschool children (Petrić, Kostadin, Peić, 2018). It is constructed to encompass their physical fitness and biotic motor knowledge, and in a certain way these are used to estimate the level of basic motor literacy (Petrić, 2019). If the metrical characteristics of the Childfit battery of tests prove acceptable, this research can be exceptionally significant. It would offer a battery of tests applicable to early and preschool children, national and international frameworks would be determined, while the standardization of children's motor achievements, as well as the level of their general motor literacy, would be made possible.

It is therefore the aim of this research to determine the metric characteristics the Childfit battery of tests for early and preschool children, i.e. to determine the validity and reliability of all four tests constructed to measure children's motor achievements in the domain of mastering space, mastering obstacles, mastering resistance and mastering the handling of objects.

\section{Methods}

\section{Description of participants}

The participants in this study are 122 early and preschool children attending kindergarten in the city of Rijeka. The kindergarten is newly built and well equipped for the educational process. The children were subsequently divided in line with the periods of early and preschool education (according to Petrić, 2019) into nursery (48) and preschool (74) groups. The nursery group has three mixed educational groups, a total of 26 girls and 22 boys with an average chronological age of 2.2. The 
preschool group has three mixed educational groups, a total of 41 girls and 33 boys, with an average chronological age of 5.3 .

\section{Description of tests}

The sample of variables is made by measurement results obtained in four tests constructed by the authors Petrić, Kostadin and Peić (2018), used for the estimation of motor achievements according to instructions given by Findak (2003) and based on various structures of movement that enable the mastering of space, obstacles, resistance and handling of objects (Petrić, 2019). Description of the conduct of the Childfit tests can be found in research conducted by Petrić, Kostadin and Peić (2018). The first test is intended to evaluate motor achievement in the domain of mastering space. The second test aims at the estimation of motor achievement in the domain of mastering obstacles. The third test aims at the estimation of motor achievement in the domain of mastering resistance. The fourth test aims to estimate motor achievement in the domain of mastering the manipulation of objects.

\section{Measurement protocol}

The research was conducted as part of the project "Establishing the system for monitoring physical activities with contemporary technology in institutions of early ages education", and fully supported by the University of Rijeka under the project number uniri-drustv-18-268. It was approved by the professional board of kindergartens, and the children's parents were told the details and signed their consent for their children to participate in the study.

In line with the research aim, children were measured twice in all tests, with a fifteen (15) day interval between. Each interval was marked by the research team visiting a certain kindergarten twice. On their first visit, the children in the nursery group were measured, and on the second, the same was done with the preschool group. The tests were carried out in the gyms of the kindergartens. The same measurers were always present at the test, and they described to children and demonstrated how a certain test had to be done. In each interval, the children repeated each test 
three times, while the final value was the the best of the three attempts. The study was conducted from $25^{\text {th }}$ May to $10^{\text {th }}$ June 2019.

\section{Statistical data analysis}

All data were processed and analysed in the programme STATISTIKA 12.5 (StatSoft, Inc., Tulsa, OK, USA). Basic descriptive parameters were calculated for each test: arithmetic mean and standard deviation. The contents, i.e. elements from which tests were constructed, were systematically analysed to determine their content value. Then the test - retest method was applied and the Pearson correlation coefficient between two measurement intervals was calculated to determine the test reliability. The statistical level of significance was tested with an error of $\mathrm{p}<0.05 \%$.

\section{Results}

Childfit tests have been constructed to measure motor achievement in the domain of mastering space, mastering obstacles, mastering resistance and mastering the handling of objects. The systematic analysis of the test contents shows that they are constructed in such a way that to perform them, it is necessary to have a certain level of motor knowledge that by its structure, belongs to a certain domain of motor skills. To successfully perform the space test, children must be able to walk or run, and when it comes to motor abilities, at least a minimum level of coordination, balance, speed, agility and precision is necessary.

To perform the obstacle test, the motor knowledge the child applies comprises depth and drop jumps, while the motor abilities used are coordination, explosive power, like the vertical jump, and speed.

The key motor knowledge necessary to perform the resistance test is moving in a push-up position with arms front, so that the child, for the duration of the test, uses the power of the arms and shoulders to master the load of a larger part of his/her mass. 
In the end, the motor knowledge necessary for successful performance of the manipulation test is rolling a ball on the ground using both arms to direct it, while the minimal motor abilities needed are coordination, power, agility and speed.

Table 1. gives the percentages and standard deviation of results on the motor achievement tests of nursery and kindergarten children. Both groups of children achieved similar results, which means that they needed the least time to successfully perform motor challenges in the space test, then obstacles and then resistance and manipulation. The kindergarten group, as expected, given their chronological age, achieved better average results on all tests compared to the nursery group. The greatest difference-an average of 5.4 seconds- was achieved in the manipulation test, the least--2.7 seconds--in the obstacle test. When the deviations (standard deviation) from average results are considered, it can be seen (Table 1.) that they are much smaller in the kindergarten group of children. The kindergarten group is more homogeneous in their motor achievements than the nursery group. The highest deviation is present in the manipulation test, the lowest in the space test.

Table 1. Basic descriptive parameters of results (seconds) on tests during the first measurement

\begin{tabular}{lcc}
\hline TEST NAME & $\begin{array}{c}\text { NURSERY } \\
(\mathrm{M} \pm \mathrm{SD})\end{array}$ & $\begin{array}{c}\text { KINDERGARTEN } \\
(\mathrm{M} \pm \mathrm{SD})\end{array}$ \\
\hline Space test & $7.43 \pm 2.41$ & $4.46 \pm 0.38$ \\
\hline Obstacle test & $9.21 \pm 2.91$ & $7.13 \pm 1.77$ \\
\hline Resistance test & $11.44 \pm 4.34$ & $8.64 \pm 1.89$ \\
\hline Manipulation test & $17.11 \pm 13.17$ & $12.7 \pm 3.01$ \\
\hline (M - mean, SD - standard deviation) &
\end{tabular}

The results of the second measurement interval with the Childfit battery of tests are given in Table 2. Both groups achieved the best results in the space test, then obstacles and resistance, while on average, they needed the most time (seconds) to successfully perform the manipulation test. The highest average difference (5.44 seconds) between the nursery and kindergarten group was achieved in the manipulation test, while the smallest (2.65 seconds) appeared in the resistance test. The repeated measurement also showed a difference in average deviations (standard deviation) within the nursery group. Table 2 . shows that the minimum average deviation in kindergarten children was achieved in the obstacle test, while the 
highest remained the same, namely, the manipulation test. In general, the deviation was somewhat smaller for both groups, which means that both groups became more homogeneous in their motor achievements after the first measurement.

Table 2. Basic descriptive parameters of results (seconds) at tests during the second measurement

\begin{tabular}{lcc}
\hline TEST NAME & $\begin{array}{c}\text { NURSERY } \\
(\mathrm{M} \pm \text { SD) }\end{array}$ & $\begin{array}{c}\text { KINDERGARTEN } \\
(\mathrm{M} \pm \text { SD) }\end{array}$ \\
\hline Space test & $7.01 \pm 2.73$ & $4.24 \pm 0.29$ \\
\hline Obstacle test & $8.96 \pm 2.39$ & $6.87 \pm 1.63$ \\
\hline Resistance test & $10.94 \pm 4.15$ & $8.29 \pm 2.06$ \\
\hline Manipulation test & $15.79 \pm 11.66$ & $10.35 \pm 2.88$ \\
\hline (M - mean, SD - standard deviation) &
\end{tabular}

Graph 1. presents the comparison of average results for the nursery group of children on all measurement tests. When considering both measurements, the children achieved the best results in the space and obstacle tests, while the poorest results were achieved in resistance and manipulation tests. The results were better after the second measurement compared to the first one. The highest average improvement of 1.32 seconds occurred on the manipulation test, and 0.5 seconds in the resistance test.

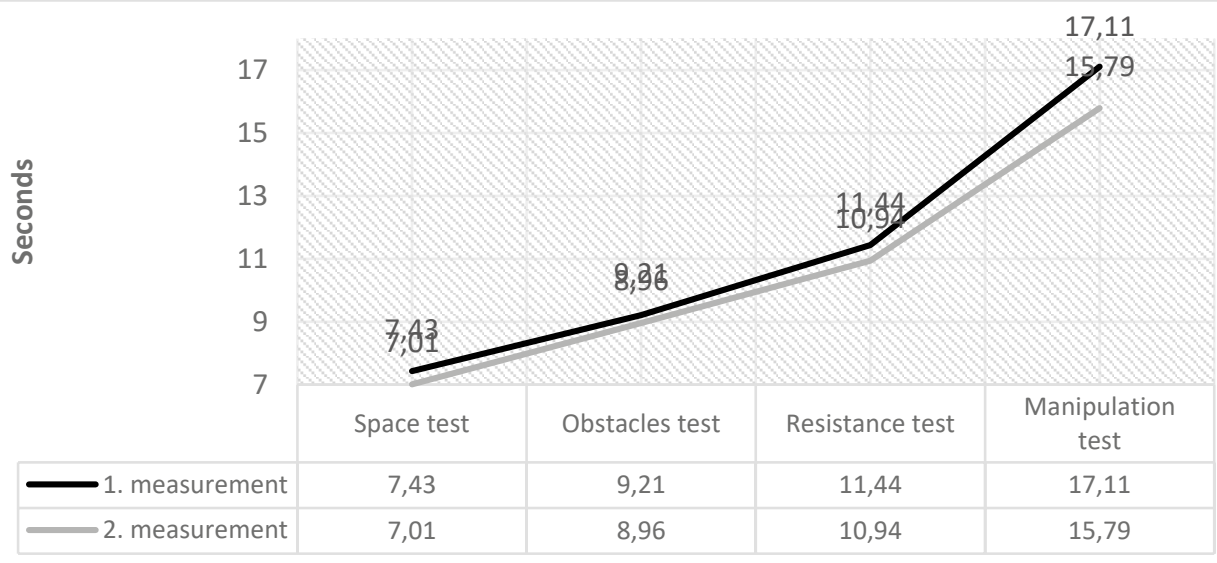

Graph 1. Comparison of average results in the nursery group after the first and second measurement 
Graph 2. presents the comparison of average results in the kindergarten group on all measured tests. Similar to the nursery group, kindergarten children, when both measurements are analysed, achieved the best average results on the space and obstacle tests, while the worst were achieved in the resistance and manipulation tests. They also achieved better results on all tests in the second measurement than in the first. The highest average improvement of 2.35 seconds was achieved in the manipulation test. For the other three tests, their improvement varies from 0.22 to 0.36 seconds.

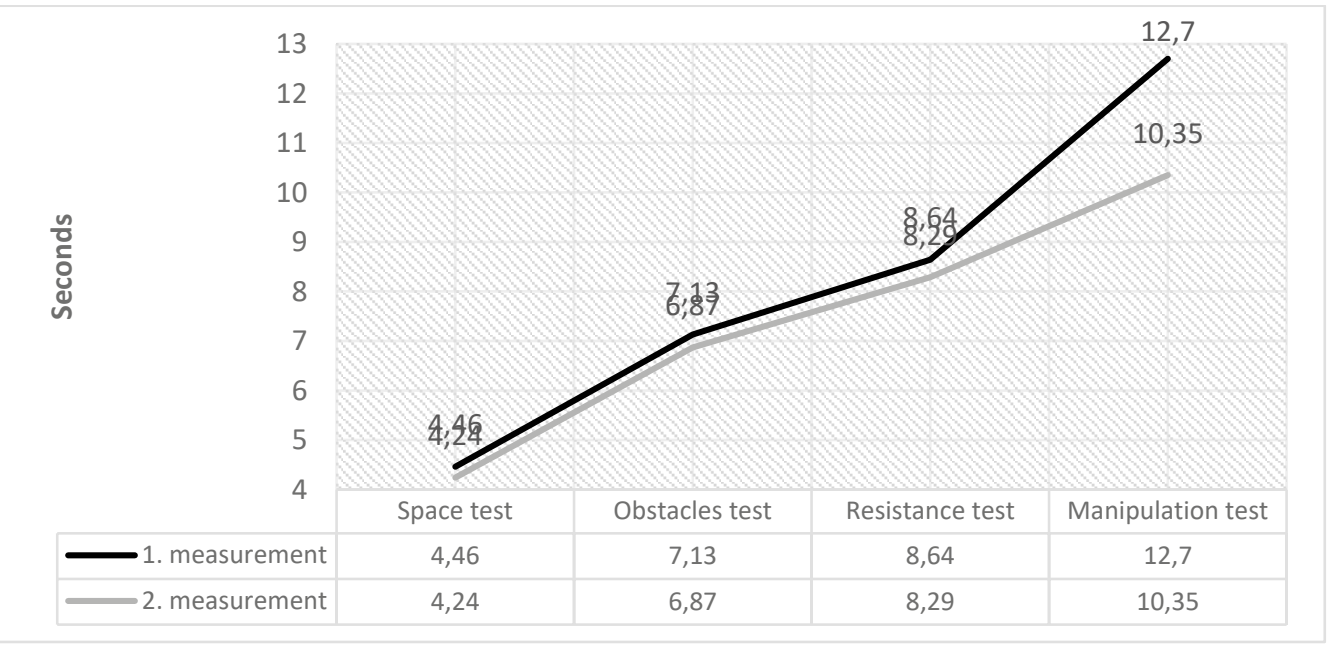

Graph 2. Comparison of average results in the kindergarten group after the first and second measurement

Table 3. shows the correlation of results between the first and second measurement interval. In the nursery and kindergarten group, the results between the two measurements are statistically significantly $(\mathrm{p}<0.05)$ correlated. The correlation $(r)$ for all tests varies from 0.91 to 0.94 . The kindergarten group has the lowest correlation of results $(\mathrm{r}=0.91)$, achieved in the obstacle and manipulation tests, while the highest $(\mathrm{r}=0.94)$ was achieved in the space test. The kindergarten group achieved the highest correlation $(r=0.93)$ among results in the obstacle test. 
Table 3. Test correlation coefficients between the first and second measurement

\begin{tabular}{lcc}
\hline TEST NAME & r - NURSERY & r - KINDERGARTEN \\
\hline Space test & $0.94^{*}$ & $0.91^{*}$ \\
\hline Obstacle test & $0.91^{*}$ & $0.93^{*}$ \\
\hline Resistance test & $0.92^{*}$ & $0.91^{*}$ \\
\hline Manipulation test & $0.91^{*}$ & $0.92^{*}$ \\
\hline (* - significance of $0,05 \%)$ & &
\end{tabular}

Generally speaking, in the nursery and kindergarten group, children achieved the best average results in the space test, and the poorest results were achieved in the manipulation test. The average results of the second measurement result are somewhat better than the first measurement results, in all tests and for both groups, while the greatest improvement was achieved in the manipulation test. The correlation of results from the two measurement intervals is statistically significant, and in all tests it is in the range from 0.91 to 0.94 .

\section{Discussion}

The content validity of the instrument encompasses the systematic analysis of items (parts) of the measuring instrument. This way of determining their validity is the most adequate for instruments examining knowledge and the level to which the examinees have mastered a certain specific skill (Mejovšek, 2008). Based on the results of the systematic content analysis, it can be derived that the Childfit tests have been constructed to measure motor knowledge and abilities, or the child's specific skills when it comes to mastering space, obstacles, resistance and the handling of objects. In other words, analysis of the sections of the Childfit tests clearly shows that each of them demands a certain type of motor knowledge specific to the domain (space, obstacles, resistance, manipulation) for which it is intended, and a certain level of motor abilities necessary to successfully perform it. Their content validity is corroborated by the methodology of their construction. They have been constructed in line with instructions for the designation of motor achievement tests (according to Findak, 2003). Therefore, the Childfit tests measure what they have been constructed for, since they ensure that all parts of the measurement object are proportionally represented, and that all items of the instrument (tests) are relevant for the measurement object. 
The question of how well an instrument measures the characteristic for which it has been constructed leads us to the metrical characteristic of reliability. The test - retest procedure for determining reliability which was applied in this research is characterised by a re-application of the instrument on the same sample of examinees after a specific time interval, and the correlation coefficient is the indicator of its stability (Mejovšek, 2008). The results, i.e. the correlation coefficient between two intervals of measurement, indicate that it is statistically significant, and in all tests it is above 0.91 . Thus, in all Childfit tests, the stability of the measurement characteristics over time is manifested. The prescribed correlation coefficient standard for ability tests is at least 0.90 (Mejovšek, 2008), which leads to the conclusion that Childfit tests do constitute a reliable instrument. In former research assessing the manageability, internal consistency, convergent construction validity and reliability of the battery of tests for measuring children's motor abilities, the correlations of the test-retest testing were high, but not in all tests (Fjortoft et al., 2011). Correlation coefficients inside a class for certain test units yielded total results in the range from 0.54 to 0.92 . The Childfit tests applied in this study gave somewhat better results.

The average results of the second measurement interval are somewhat better than the first measurement results, in all tests and for both groups. This fact can be considered one of the major drawbacks of the test - retest procedure. Namely, during the second application of the instrument, the participants can remember their first performance of certain motor requirements of the test, so better results can always be expected (Mejovšek, 2008). However, higher results in the second measurement will not influence the height of the correlation if the same differences among examinees recur in the second measurement.

In both groups of children, the best results were achieved in the domain of space and obstacles. This is not surprising, since this knowledge is mostly used by children in their everyday movements and games, while they use mastery of resistance to a lesser extent (for instance, lifting, carrying, hanging, swinging, pushing, etc.), especially when it comes to the knowledge of how to handle an object (for instance, catching, throwing, aiming, leading, etc.). Motor content in the domain of handling of objects is more complex than the ones already mentioned, so in this area, 
encouragement to enable the child to master that, develop and improve is especially important (Petrić, 2019). The development of this domain is the least represented in children's everyday life and games, so among other things, by repeating the manipulation test, they formed motor data in the central nervous system which they do not use very often. Today it is known that motor improvement is directly linked to the central nervous system in our bodies (Jensen, 2005), so this fact can partly explain the occurrence of the greatest improvement in the manipulation test.

Petrić et al (2018) used the Childfit tests in their research to evaluate the effects of an integrated programme of physical exercise with nursery children. Results have shown that this programme achieved excellent results in the improvement of children's motor skills. When it comes to statistics, the experimental group achieved results $(\mathrm{p}=0.00)$ in all variables (space, obstacles, resistance, manipulation) that were significantly better than the control group. The average results obtained by test measurements are somewhat lower than this study's average results. It should nevertheless be taken into consideration that these research participants are children attending a kindergarten that has been a teacher training centre for the Faculty of Teacher Education of the University of Rijeka for eight years, and everyday physical exercise has been established through various kinesiological activities. All of these are based on biotic motor knowledge and conducted by educated preschool teachers in collaboration with the kinesiology professor from the same faculty. This is certainly one reason that children participating in this research achieved better average results.

Childfit tests measure motor achievements in four domains which together make a whole and enable children's motor expression in space (Petrić, 2019). As a corollary, it can be affirmed that these tests estimate a child's general motor literacy. A lack of general motor literacy, which is the base for children's further development and the quality of their lives, is more frequently noticed among nursery and preschool children. Children's motor skills are directly connected to the development of the central nervous system, and a lack of movement in early childhood cannot be recovered later in life (Pišot and Planinšec, 2005). Research indicates that a child's entrance to an educational institution marks the stagnation or even deterioration of their motor skills (Novak et al., 2014), which could also indicate preschool teachers' 
limited understanding of the importance of implementing movement in everyday activities. Institutional education, despite contemporary paradigms, still depends on a structure that often neglects the importance of movement for children (Brockman, Jago and Fox, 2010). Children spend a considerable part of their day in early education institutions (Hyndman, Benson and Telford, 2016), so the competences of those professionals who spend time there with them are important, but also their opinion about the importance of movement in educational work. The diagnosis of motor achievements done with Childfit tests can become the basis for planning and programming the educational process by professionals who work with children. The results could serve to highlight the importance of movement, the level of children's motor achievements, or their general motor literacy, and indicate where to direct the educational work when it comes to physical exercise.

\section{Conclusion}

Analysis and discussion of the results lead to the conclusion that Childfit tests satisfy the validity and reliability criteria and are applicable for the measurement of early and preschool children's motor achievements. The tests include all domains of movement used by children every day for their motor functioning: mastering space, obstacles, resistance and handling of objects. Besides motor achievements, the Childfit tests estimate the level of children's general motor literacy. However, those results should be treated with caution, given the small number of previous studies.

This research represents a breakthrough in the diagnosis of motor knowledge, fitness and general motor literacy for early and preschool children. Further research projects should be directed toward the determination of result rates at the national and international levels. Thus, insight into standardized results could be gained, which would simplify assessment and comparison in other research studies that apply the Childfit tests and evaluate the effect of the educational work. 
The Childfit battery of tests can form the basis for motor diagnosis in early and preschool education. It also diagnoses potential motor deficiencies that can be influenced by physical exercise, while the professional working with the child is thus enabled to completely adapt his or her educational work to their needs.

\section{References}

Artero, E. G., España-Romero, V., Castro-Piñero, J., Ortega, F. B., Suni, J., Castillo-Garzon, MJ., Ruiz, JR. (2011). Reliability of field-based fitness tests in youth. International Journal of Sports Medicine, 32(3), pp. 159-69.

Brockman, R., Jago, R., Fox, K.R. (2010). The contirbuion of active play to the physical activity of primary school children. Preventive Medicine, 51, pp. 144-147.

Castro-Pinero, J., Artero, E. G., Espana- Romero, V., Ortega, F. B., Sjostrom, M., Suni, J., et al. (2010). Criterion related validity of field- based fitness tests in youth: A systematic review. British Journal of Sports Medicine, 44: pp. 934-943.

Cvejić, D., Pejović, T., Ostojić, S. (2013). Assessment of physical fitness among children and adolescents. Physical education and sport, 11(2): pp. 135-145.

Findak, V., Prskalo, I. (2004). Kineziološki leksikon za učitelje. Petrinja, Visoka učiteljska škola.

Findak, V. (2003). Metodika tjelesne i zdravstvene kulture. Zagreb, Školska knjiga.

Fjørtoft, I., Pedersen, AV., Sigmundsson, H., Vereijken, B. (2011). Measuring physical fitness in children who are 5 to 12 years old with a test battery that is functional and easy to administer. Physical Therapy, 91(7), pp. 1087-95.

Hyndman, B., Benson, A., Telford, A. (2016). Active play: exploring the influences on children's school playground activitie. American Journal of Play, 8(3), pp. 325-344.

Jensen, E. (2005). Poučavanje s mozgom na umu. Zagreb: Educa.

Novak, D., Petric, V., Jurakic, D., Rakovac, M. (2014). Trends and Future Visions of Physical Education: Croatian Challenges. In M-K. Chin, C.R. Edginton (Eds.), Physical education and bealth - Global Perspectives and Best Practice (pp. 121-133). Urbana, IL: Sagamore Publishing.

Ortega, FB., Cadenas-Sánchez, C., Sánchez-Delgado, G., Mora-González, J., Martínez-Téllez, B., Artero, E. G., Castro-Piñero, J., Labayen, I., Chillón, P., Löf, M., Ruiz, J. R. (2015). Systematic review and proposal of a field-based physical fitness-test battery in preschool children: the PREFIT battery. Sports Medicine, 45(4), pp. 533-55.

Petrić, V. (2019). Kineziološka metodika u ranom i predškolskom odgoju i obrazovanju. Sveučilište u Rijeci, Učiteljski fakultet.

Petrić, V., Kostadin, L., Peić, M. (2018). Evaluation of an Integrated Programme of Physical Exercise with Nursey-Aged Children: Impact on Motor Achievements. Journal of Elementary Education, 11(3), pp. 189-200.

Ruiz, JR., Castro-Piñero, J., España-Romero, V., Artero, E. G., Ortega, F. B., Cuenca, M. M., Jimenez-Pavón, D., Chillón, P., Girela-Rejón, M. J., Mora, J., Gutiérrez, A., Suni, J., Sjöström, M., Castillo, M. J. (2011). Field-based fitness assessment in young people: the ALPHA health-related fitness test battery for children and adolescents. British Journal of Sports Medicine, 45(6), pp. 518-24. 


\section{Author}

\section{Vilko Petrić, PhD}

University of Rijeka, Faculty of Teacher Education, Sveučilišna avenija 6, 51000 Rijeka, Croatia, email: vilko.petric@uniri.hr

Univerza v Reki, Fakulteta za izobraževanje učiteljev, Sveučilišna avenija 6, 51000 Reka, Hrvaška, email: vilko.petric@uniri.hr 